\title{
Mapping differential vulnerabilities and rights: 'opening' access to social protection for forcibly displaced populations
}

Rachel Sabates-Wheeler(i)

Correspondence: r.sabateswheeler@ids.ac.uk

Institute of Development Studies, University of Sussex, Falmer, Sussex BN1 9RE, UK

\begin{abstract}
In recent years, forcibly displaced populations have attracted enormous media attention as an increasing number of disasters and political conflicts push more and more people to move away from their homes and seek refuge and opportunities in other places. At the same time, political nervousness about the financial and institutional capability of 'receiving' locations to adequately respond to the needs of these large-scale population movements contributes to the shrinking space for thinking about the rights and needs of people on the move. It is precisely because of these global trends that the plight of forcibly displaced populations is becoming more precarious and vulnerable, yet standard social protection provision rarely attends to the plight of these people. The purpose of this paper is to elaborate the remit and implications for including a consideration of forcibly displaced populations (including internally displaced people, refugees and asylum seekers) within social protection policy and programming. Drawing on a limited number of recent initiatives, we suggest some ways in which social protection can be 'opened' for these groups.
\end{abstract}

Keywords: Social protection, Forcibly displaced, Refugees, Vulnerability, Rights

\section{Introduction}

Over the last 20 years social protection has risen up the development agenda, so much so that it sits firmly within the global development architecture as a critical pillar to supporting social and economic development (see Barrientos \& Hulme, 2008; Devereux \& Sabates-Wheeler, 2004; Gentilini \& Omamo, 2011; Surender \& Walker, 2013). The majority of the literature and work on social protection has focused on the protection and provision of social assistance, social insurance and social services to vulnerable and poor populations in the global south. These populations are typically citizens or habitual residents of specific nation states, resulting in the majority of policy and programming efforts being developed by national Governments, or by national Governments in collaboration with support from international development support. A notable and increasing (yet relatively small) exception to this has been research that documents and interrogates the relationship between labour migration and social protection. This literature has been critical to shifting the framing of social protection away from the constraints imposed by the nation state - instead allowing a discourse to emerge

(c) The Author(s). 2019 Open Access This article is distributed under the terms of the Creative Commons Attribution 4.0 International License (http://creativecommons.org/licenses/by/4.0/), which permits unrestricted use, distribution, and reproduction in any medium, provided you give appropriate credit to the original author(s) and the source, provide a link to the Creative Commons license, and indicate if changes were made. 
regarding how people are able to claim social rights beyond borders. Work in this area has expanded in the areas of: (i) portability of social rights (such as pensions and healthcare) across borders and within economic trading zones protection (Avato, Koettl, \& Sabates-Wheeler, 2010; Olivier, 2009); (ii) inequities in access to social rights for different categories of labour migrants (Sabates-Wheeler \& Feldman, 2011); (iii) labour market regulations that cover migrants provision to social protection; and, (iv) the structures of informal and transnational social protection and care systems for low-income migrants, particularly those that might move undocumented, or into the informal labour market of a destination country (Boccagni, 2011). ${ }^{1}$

Attention to forcibly displaced populations within the social protection field has been limited. That which is available is typically informed by research from the global North (see Ambrosini, 2017, 2018 and Sainsbury, 2012). This limit in focus is understandable due to the difficulties of establishing where the responsibility for provision of social rights lie -- especially in the case of refugees who are outside their country of residency. The political economy of provision for refugees and many IDP groups can be extremely complex, especially if the ruling party or State intentionally decides not to recognise the rights of the forcibly displaced groups. Furthermore, locating and providing for people on the move can be logistically very complicated. Yet, despite these challenges, the current global heightened concerns about large movements of displaced populations (whether due to political conflict or climate effects) means that there is imperative to consider how these groups can claim their social rights.

The purpose of this paper is to elaborate the remit for including a consideration of forcibly displaced populations (including internally displaced people (IDP), refugees and asylum seekers) within social protection provision. This will involve laying out the specific disadvantages and vulnerabilities that forcibly displaced populations face, with attention given to the gendered vulnerabilities of displacement. Our purpose in doing this is to draw out the implications of displacement for access to and design of social protection policies, programmes and systems. While still a limited field of research, we hope to understand better the opportunities currently available for adapting and building social protection responses to serve the needs of the forcibly displaced.

The rest of this paper comprises the following sections. First, we define and describe the specific groups and populations of interest in this paper, laying out the vulnerabilities and associated needs for social protection that these groups have by nature of their displacement. We then describe the legal rights ascribed to specific sub-groups of displaced populations. The third section highlights the opportunities currently afforded by international global commitments as well as innovations in social protection to cater for displaced populations within the design and delivery of social protection. The paper concludes by offering suggestions for how social protection can cater for forcibly displaced populations and identifies areas where further work is needed.

\section{Differentiating forcibly displaced populations}

There are a number of terms used to describe different groups of forcibly displaced people, some of which have specific legal force and others of which are intended to

\footnotetext{
${ }^{1}$ Interesting research in this area provides rich analysis on transnational social protection in the context of gendered care work and care responsibilities.
} 
underline specific vulnerabilities. These include those mapped as part of Table 1, below. In this paper we focus on forcibly displaced populations, specifically refugees, asylum seekers and IDPs. ${ }^{2}$ Returnees are included in the table below as they frequently constitute just another phase in the movement of displaced groups. The drivers and experience of movement are different for the various groups. For instance, refugees are recognized as such based on the grounds of movement due to persecution. This movement can be mass movements of large numbers or individual and family movement, where journeys are frequently clandestine and rely upon smuggling networks. Whereas, returnee movements in response to improved security and peace at the home location might be in the form of 'spontaneous return' or as organized mass repatriation (sometimes involuntarily) with international assistance (we do not consider the situations of returnees in depth). Moreover, the notion of mixed migration suggests that people may start out as forced migrants (e.g. persecution) but then continue as labour migrants once they leave the place of first refuge to move on for economic opportunities.

\section{Forced displacement, vulnerability and the need for social protection}

There are an estimated 244 million people currently living in a country other than that of their birth. ${ }^{3}$ This includes 21.3 million refugees who have fled war and persecution, as well as other populations that have been displaced as a result of insecurity, natural disaster or the effects of climate change. In addition to this there are an estimated 38 million IDPs who have been forced to leave their homes. ${ }^{4}$ The magnitude of vulnerability for these groups is obvious, simply by virtue of the large and increasing numbers as well as the high levels of insecurity that these populations often face, such as the absence of family and community networks, and the inability to reach and/or settle in safe areas.

Social protection in all its forms (state-provided, market, informal) is, fundamentally, a policy response to vulnerability (see Barrientos \& Hulme, 2008; Sabates-Wheeler \& Devereux, 2008). As discussed in the introduction to this special issue, social protection describes all public and private initiatives that provide income or consumption transfers to the poor, protect the vulnerable against livelihood risks, and enhance the social status and rights of the marginalised (Devereux \& Sabates-Wheeler, 2004). Social protection interventions - or the lack of them - can play a part in terms of precipitating, directing or halting movement (e.g. from a country of origin without a functioning social protection system).

Forcibly displaced populations face a range of vulnerabilities, some specific to their reasons for moving and some specific to their legal status. Other vulnerabilities are not displacement-specific, but related to the places and sectors in which people find themselves. For instance, refugees hosted within the destination population (as opposed to a camp) may find themselves exposed to risks associated with precarious low-wage

\footnotetext{
${ }^{2}$ We do not consider migrants who move predominantly to seek employment as the issues facing these populations can be substantially different. For a review of the social protection needs and opportunities for labour migrants see Avato et al. (2010).

${ }^{3} \mathrm{UN}$ Department of Economic and Social Affairs (DESA), International Migration Report 2015: Highlights. ST/ESA/SER.A/375, 2016, p.1.

${ }^{4}$ Internal Displacement Monitoring Centre, Global Figures, http://www.internal-displacement.org/globalfigures
} 
Table 1 Definitions of different groups of forcibly displaced populations and reasons for movement

\begin{tabular}{|c|c|c|}
\hline Group & Definition & Drivers of Movement \\
\hline \multirow[t]{5}{*}{ Refugees } & $\begin{array}{l}\text { The } 1951 \text { Convention on the Status of } \\
\text { Refugees, defines refugees as those } \\
\text { individuals who 'owing to well-founded fear } \\
\text { of being persecuted for reasons of race, reli- } \\
\text { gion, nationality, membership of a particular } \\
\text { social group or political opinion, [are] out- } \\
\text { side the country of his nationality and [are] } \\
\text { unable or, owing to such fear, [are] unwill- } \\
\text { ing to avail himself of the protection of that } \\
\text { country'a }\end{array}$ & \multirow{5}{*}{$\begin{array}{l}\text { Primary: } \\
\text { - Persecution } \\
\text { - Events seriously disturbing public order } \\
\text { - Generalized violence } \\
\text { - Massive human rights violations } \\
\text { - Conflict } \\
\text { - Lack of state protection } \\
\text { - Movement is gender and age-biased de- } \\
\text { pending on culture and context } \\
\text { Secondary (especially important in } \\
\text { choosing destination): } \\
\text { - Poverty/Opportunity } \\
\text { - Diaspora/family connections } \\
\text { Second and third generation refugees may } \\
\text { never have engaged in migration, but } \\
\text { have been born into exile. }\end{array}$} \\
\hline & $\begin{array}{l}\text { In Africa, the } 1969 \text { OAU Convention further } \\
\text { included those fleeing 'events seriously } \\
\text { disturbing the public order'b }\end{array}$ & \\
\hline & $\begin{array}{l}\text { The } 1984 \text { Cartagena Declaration similarly } \\
\text { expanded the definition to cover those } \\
\text { fleeing 'generalized violence, foreign } \\
\text { aggression, internal conflicts, massive } \\
\text { violation of human rights or other } \\
\text { circumstances which have seriously } \\
\text { disturbed public order' in Latin America, } \\
\text { Mexico and Panamac }\end{array}$ & \\
\hline & $\begin{array}{l}\text { Palestinian refugees are defined by the } \\
\text { United Nations' Relief and Work Agency } \\
\text { (UNRWA) as those 'whose normal place of } \\
\text { residence was Palestine during the period } 1 \\
\text { June } 1946 \text { to } 15 \text { May 1948, and who lost } \\
\text { both home and means of livelihood as a } \\
\text { result of the } 1948 \text { conflict', as well as their }^{\text {patrilineal descendants }}{ }^{d}\end{array}$ & \\
\hline & $\begin{array}{l}\text { In cases of mass influx due to conflict or } \\
\text { violence, it is not always possible or } \\
\text { necessary to conduct individual interviews } \\
\text { to determine an asylum claim. Depending } \\
\text { on the legal system in place, refugees' } \\
\text { claims may instead be recognized on a } \\
\text { prima facie basis due to 'readily apparent' } \\
\text { circumstances in the country of origin (e.g. } \\
\text { Syrians, Somalis). }\end{array}$ & \\
\hline Asylum Seekers & $\begin{array}{l}\text { An individual who has made a claim for } \\
\text { refugee status, but whose individual claim } \\
\text { has not yet been subject to determination, } \\
\text { either by national authorities or by UNHCR }\end{array}$ & As refugees \\
\hline $\begin{array}{l}\text { Internally Displaced } \\
\text { Persons }\end{array}$ & $\begin{array}{l}\text { IDPs are those who have been forced to } \\
\text { flee their home, 'in particular as a result of } \\
\text { or in order to avoid the effects of armed } \\
\text { conflict, situations of generalized violence, } \\
\text { violations of human rights or natural or } \\
\text { human-made disasters, and who have not } \\
\text { crossed an internationally recognized } \\
\text { border'e }\end{array}$ & $\begin{array}{l}\text { Primary: } \\
\text { - Persecution } \\
\text { - Conflict } \\
\text { - Generalized violence } \\
\text { - Human rights violations } \\
\text { - Natural or man-made disasters (e.g. earth- } \\
\text { quake, famine) } \\
\text { - Climate change } \\
\text { Secondary: } \\
\text { - Poverty/Opportunity } \\
\text { - Language/Ethnic connections }\end{array}$ \\
\hline Returnees & $\begin{array}{l}\text { Returnees include refugees voluntarily } \\
\text { repatriating at the end of conflict, as part of } \\
\text { a "durable solution" to their displacement. } \\
\text { Equally, failed asylum seekers and other } \\
\text { migrants moving or staying irregularly may } \\
\text { be subject to enforced removals and/or } \\
\text { offered assistance to return and reintegrate } \\
\text { voluntarily to their country of origin (AVRR). }\end{array}$ & $\begin{array}{l}\text { Primary (refugees): } \\
\text { - Improved security/peace } \\
\text { - Improved development prospects } \\
\text { - Family reunification } \\
\text { Primary (other migrants): } \\
\text { - Legal deportation } \\
\text { - AVRR programme } \\
\text { - Care responsibilities and family } \\
\text { reunification }\end{array}$ \\
\hline Other forcibly & People may also be forced to cross a border & Primary: \\
\hline
\end{tabular}


Table 1 Definitions of different groups of forcibly displaced populations and reasons for movement (Continued)

\begin{tabular}{|c|c|c|}
\hline Group & Definition & Drivers of Movement \\
\hline $\begin{array}{l}\text { displaced (including } \\
\text { climate change) }\end{array}$ & $\begin{array}{l}\text { for reasons other than conflict or } \\
\text { persecution, for instance as a result of } \\
\text { natural disaster or climate change. } \\
\text { Depending on where they are, such } \\
\text { persons often do not qualify for refugee } \\
\text { status, but they be granted humanitarian } \\
\text { leave or some other form of temporary } \\
\text { protection (e.g. the US' "Temporary } \\
\text { Protected Status") }\end{array}$ & $\begin{array}{l}\text { - Natural or man-made disasters (e.g. earth- } \\
\text { quake, famine) } \\
\text { - Climate change } \\
\text { - Insecurity } \\
\text { Secondary: } \\
\text { - Poverty/Opportunity } \\
\text { - Diaspora/family connections }\end{array}$ \\
\hline
\end{tabular}

aUN General Assembly, Convention Relating to the Status of Refugees, 28 July 1951, United Nations, Treaty Series, vol. 189, p. 137. Retrieved from http://www.refworld.org/docid/3be01b964.html

borganization of African Unity (OAU), Convention Governing the Specific Aspects of Refugee Problems in Africa ("OAU Convention"), 10 September 1969, 1001 U.N.T.S. 45. Retrieved from http://www.refworld.org/docid/3ae6b36018.html 'Regional Refugee Instruments \& Related, Cartagena Declaration on Refugees, Colloquium on the International Protection of Refugees in Central America, Mexico and Panama, 22 November 1984. Retrieved from http://www.refworld.org/docid/3ae6b36ec.html

dUnited Nations Relief and Works Agency, Palestinian Refugees. Retrieved from http://www.unrwa.org/palestine-refugees eUN Commission on Human Rights, Report of the Representative of the Secretary-General, Mr. Francis M. Deng, submitted pursuant to Commission resolution 1997/39. Addendum: Guiding Principles on Internal Displacement, 11 February 1998, E/

CN.4/1998/53/Add.2. Retrieved from http://www.refworld.org/docid/3d4f95e11.html, Art. 2

fUnited States Citizen and Immigration Service, Temporary Protected Status. Retrieved

from https://www.uscis.gov/humanitarian/temporary-protected-status

employment. Vulnerabilities may also be influenced by an individual or group's characteristics (e.g. gender or age) and may change over time and through different stages of a migration journey. For instance, social protection may protect women in transit from specific sorts of harm that they may encounter along the journey. Anecdotal evidence suggests that women on the San Diego- Mexican border pay larger fees to smugglers than men because they prefer to cross at official points with false documents in order to avoid sexual and gender-based violence (SGBV) at the hands of the coyotes. ${ }^{5}$ The needs of migrants and displaced populations are diverse and reflect the contexts (environmental, cultural and political) to which they move or settle into.

Table 2, below, illustrates the categories of disadvantage and the different determinants of vulnerabilities faced forcibly displaced persons. Displacement-specific disadvantage applies by virtue of having to move or be re-located. For instance, some refugees are only able to reach a place of safety by relying on smuggling networks, placing them at risk of exploitation, abuse or harm on a dangerous journey. Women are often doubly disadvantaged as they are frequently less able to defend themselves against physical abuse and exploitation. Refugees, especially those living in a campbased setting, may experience specific challenges related to access to employment opportunities. In addition, IDPs frequently face socio-cultural disadvantage through systematic discrimination and denial of their rights and entitlements as citizens or legal residents. Displacement-intensified disadvantage occurs when a negative outcome is intensified for a displaced population. In other words, it is not specific to those being displaced -- it can be equally real for some groups that are not displaced, such as the urban poor who are marginalized in terms of rights and live in areas with poor public and social service provision. For displaced populations, particularly IDPs and refugees, it is often the case that upon arrival to a new location they are 'housed' in areas where

\footnotetext{
${ }^{5}$ Fleury, A.,https://unu.edu/publications/articles/fleeing-to-mexico-for-safety-the-perilous-journey-formigrant-women.html
} 
Table 2 Categories of refugee and other forcibly displaced persons' disadvantages

\begin{tabular}{|c|c|c|c|c|}
\hline \multirow{2}{*}{$\begin{array}{l}\text { Determinant } \\
\text { of } \\
\text { vulnerability }\end{array}$} & \multicolumn{4}{|c|}{ Examples of manifestations } \\
\hline & $\begin{array}{l}\text { Displacement- } \\
\text { specific }\end{array}$ & Intensified & $\begin{array}{l}\text { Bureaucratically } \\
\text { imposed }\end{array}$ & Over-representation \\
\hline $\begin{array}{l}\text { Spatial / } \\
\text { environmental }\end{array}$ & $\begin{array}{l}\text { Restrictions on } \\
\text { movement (e.g. } \\
\text { encampment). } \\
\text { Unfamiliarity with } \\
\text { surroundings } \\
\text { (unsure about } \\
\text { rights and access). } \\
\text { Increase in } \\
\text { gender-based } \\
\text { violence } \\
\text { Family Split }\end{array}$ & $\begin{array}{l}\text { Lack of knowledge (of } \\
\text { e.g. rights, opportunities } \\
\text { for transport) } \\
\text { Double intensity for } \\
\text { women and dependents }\end{array}$ & $\begin{array}{l}\text { Use of local languages } \\
\text { (can't understand access } \\
\text { rules) }\end{array}$ & $\begin{array}{l}\text { Health risks } \\
\text { associated with } \\
\text { informal settlements } \\
\text { (difficult to spend time } \\
\text { accessing). }\end{array}$ \\
\hline Socio-political & $\begin{array}{l}\text { Lack of } \\
\text { representation } \\
\text { (ineligible to } \\
\text { access, camps run } \\
\text { without } \\
\text { representation) }\end{array}$ & $\begin{array}{l}\text { Uncertainty interacting } \\
\text { with govt/agencies } \\
\text { (opaque institutional } \\
\text { complaints mechanisms) }\end{array}$ & $\begin{array}{l}\text { Discrimination in access } \\
\text { to services; (ineligible to } \\
\text { access). } \\
\text { Gender-bias in } \\
\text { legislation }\end{array}$ & $\begin{array}{l}\text { Restrictions on } \\
\text { political activities in } \\
\text { camp esp. for women } \\
\text { and youth (inability to } \\
\text { express voice). }\end{array}$ \\
\hline Socio-cultural & $\begin{array}{l}\text { Xenophobia } \\
\text { (discrimination in } \\
\text { access) }\end{array}$ & $\begin{array}{l}\text { Social discrimination } \\
\text { based on ethnicity, } \\
\text { language, illegal status, } \\
\text { gender and age } \\
\text { (discrimination in } \\
\text { provision). }\end{array}$ & $\begin{array}{l}\text { Additional stigmatising } \\
\text { requirements to access } \\
\text { services (required to } \\
\text { show additional eligibility } \\
\text { documents) }\end{array}$ & $\begin{array}{l}\text { Social perceptions of } \\
\text { 'criminal poor' } \\
\text { (additional scrutiny of } \\
\text { access documents) }\end{array}$ \\
\hline
\end{tabular}

Source: Adapted from Sabates-Wheeler and Waite (2003, p. 13)

poorer residents are located and are therefore exposed to the same disadvantages as the sedentary population, such as lack of access to the formal labour market, payment below minimum wage, and lack of access to health and education services. HagenZanker, Ulrichs, Holmes, and Nimeh (2017), in their work looking at Syrian refuges in Jordan, illustrate the range of vulnerabilities facing refugees in relation to housing and education access. In such cases, due to the irregular nature of their status, they cannot easily appeal for formal protection.

Bureaucratically imposed disadvantage refers to officials' attitudes and ideas that exacerbate customary discrimination. For instance, asylum processing can be very lengthy, bureaucratic and opaque, leaving refugees unable to fully enjoy the rights guaranteed to them under international law. Based on a case study of the Kakuma refugee camp in north Kenya, Bartolomei, Pittaway, and Pittaway (2003) show how the loss and denial of citizenship experienced by refugee women, as one of the intersecting forms of oppression and discrimination, determines their identity. Internal moves can also be hindered by bureaucratic hurdles. In India, access to the public distribution system (PDS) (food allowances), is defined by residency status within State boundaries. Access to the PDS is only available if a move is registered -- which involves a lengthy bureaucratic process (MacAuslan, 2011). In China, the Hukou (household registration system) means that social protection rights and access are determined by rural or urban residency designation, and this cannot be easily altered (Pong, 2014). Forcibly displaced people suffer over-representation disadvantage when they constitute a disproportionate share of an excluded or marginalized group. This can happen when displaced people are ghettoized into specific locations, ie, in urban slums. There are multiple health and safety risks associated with these areas that refugees and IDPs are particularly vulnerable to, simply because they are overrepresented in these areas. 
Pittaway and Rees (2006) explain how specific and compounding risks related to being in camps or fleeing from home cumulate, lead to multiple jeopardy for refugee women, who are more vulnerable to domestic violence.

\section{Gender, displacement and vulnerability}

Decisions (forced or voluntary) to move frequently take place within the portfolio of options on offer to an entire family/household. These decisions are gendered, significantly impacting familial and gendered patterns of care. Kofman and Raghuram (2010) show how transnational families between less developed and more developed countries are increasingly interconnected by way of 'care regimes' and 'global care chains'. Similarly, Bilecen and Barglowski (2015) discuss how transnational living is of strategic important for understanding the fragmented worlds of social protection. Depending on the context of movement (whether movement happens in response to perceived opportunities or due to displacement) families are often split across geographic space along lines of gender and age. Adult men and male youth frequently have more opportunities to move away from disasters or in response to job opportunities, leaving older persons, spouses and young children at home. This can exacerbate the vulnerabilities of those left at home in relation to regular income, control of land and access to credit.

In the case of refugees, more than $50 \%$ of the world's refugees are women and girls (UNWomen, 2016). ${ }^{6}$ Violence against women is rampant during armed conflict. As reported by Pittaway and Bartolomei (2018), found that rape and other forms of sexual torture are used routinely as strategies of war in order to shame and demoralize individuals, families, and communities. Furthermore, resettlement policies have historically been key in discriminating against women on grounds of both race and gender. These facts provide ample justification for why social protection for displaced populations needs to be sensitive to gender. There are afew recent exceptions where refugee women and children are given priority treatment, such as in the UK's Vulnerable Persons Resettlement (VPR) programme that provides a route for up to 20,000 Syrian refugees to be resettled in the UK. The programme prioritizes refugees who cannot be supported effectively in the Syrian region, including women and children at risk, the elderly, those in severe need of medical care, victims of torture and sexual violence, and the disabled. ${ }^{7}$ In the last 5 years Canada, also, has made changes in its refugee policy by prioritizing Syrian women and children for refugee status.

\section{Social protection provision and displacement}

Given the different vulnerabilities that displaced populations face, there will be a range of different social protection responses to these. Social protection can be broadly mapped over three categories - social assistance to the extremely poor (e.g. cash or food support through transfers, food aid, school feeding); social insurance which provides resilience against livelihood shocks and the risk of becoming poor(er) (e.g. informal savings groups, contributory unemployment or maternity benefits); and complementary initiatives to

\footnotetext{
${ }_{6}^{6}$ http://www.unwomen.org/en/news/in-focus/women-refugees-and-migrants

${ }^{7}$ See Centre for Social Justice paper (Feb 2017): The Syrian Refugee Crisis: a resettlement programme that meets the needs of the most vulnerable, accessed on 14/06/2018 at: https://www.centreforsocialjustice.org.uk/ core/wp-content/uploads/2017/02/The-Syrian-Refugee-Crisis-Final-002.pdf.
} 
ensure and improve access to social protection (for instance, through legislation or through provision of social services that enable conditions of cash transfers to be adhered to, or through awareness raising campaigns to increase knowledge of rights). ${ }^{8,9}$ An example of a complementary initiative would be in the case where an asylum seeker is unaware of their rights and unable to read the forms necessary to obtain provision. The initiative would be the provision of information and sensitization to rights as well as the provision of translation services to overcome language barriers as these will complement social protection provisioning.

Not all social protection is provided through states and markets, as many of the articles in this special issue illustrate, but instead it is provided through informal avenues (relying on community, kin, clan or other forms of reciprocity). This is especially true in contexts where formal state-based social protection is weak and family and kinship networks are dense. Often forcibly displaced people are moving from and to contexts of poor state-provided social protection. Further, even where formal provision is available, the displaced population may not have rights to the provision, causing them to depend relatively more on informal networks. In a study on Polish migrants in Germany, Barglowski, Krzyżowski, and Świątek (2015) show that informal protection, in particular with regards to care, is regarded as superior to formal social protection as it enables the maintenance of family belonging, language, and emotions. While this paper recognises the importance of these forms of social protection, we are primarily interested in assessing formal social protection policy and provision.

Formal social protection is normally conceived of as state-led, but in certain contexts - particularly when considering forced displacement - non-state, internationally-led social protection is the norm (for instance, provided by the UN or donors). This is usually because there are significant institutional and democratic deficits in the majority of contexts where large-scale forced displacement occurs, the institutional and political contexts are in crisis and national social protection system often do not exist. Under these types of circumstances the international humanitarian sector plays a critical role in provision as it operates on principles of humanity, impartiality, neutrality and independence - meaning that it has a non-political mandate for ensuring the protection and welfare of displaced groups in need. ${ }^{10}$ An obvious exception to this is illustrated in recent European movements where states are the primary providers of social protection (as the systems were already in place). Although, in Greece during the 2015-2016 refugee crisis the UNHCR operated as it would in other zones of major displacement - in other words, the State was not the primary provider of social provision due, in part, to the enormity of the challenges.

\footnotetext{
${ }^{8}$ See definition and conceptualisation of social protection in the European Development Report, 2010/2011: Social Protection for Inclusive Development: A new perspective in EU Cooperation with Africa.

${ }^{9}$ While all definitions of social protection include, at their core, the social assistance element and often the social insurance element, not all definitions are as broad as the one we are proposing (above) for framing this paper. However, it is clear that over the past 10 years we have seen the social protection discourse and space evolving to encompass a strong rights-based element as well as a recognition that standard social protection instruments can achieve strong positive livelihood and growth outcomes when coordinated with other sectoral initiatives. See Sabates-Wheeler and Devereux (2013) and Sabates-Wheeler, Abdulai, Wilmink, De Groot, and Spadafora (2017).

${ }^{10}$ Sphere Handbook, 2011.
} 
Where national systems do exist for forcibly displaced people, sometimes the provision and targeting may be so politicized that the population experiencing displacement are precisely those who are actively excluded from provision. Sainsbury (2012) describes the process of rights contraction for foreigners under the Thatcher and Major British conservative governments. Political framing of the topic of foreigners' abuse of benefits irrespective of entry category under these governments meant that negative labelling from 'the top' sent a message that British benefits were a magnet for attracting unwanted immigrants. 'This allowed the political justification for cutbacks to those eligible for benefits and, as a consequence, benefits were pegged as a lower rate for asylum seekers setting a precedent in differentiating the benefits of non-citizens and citizens' (Sainsbury, 2012, p. 167/8).

Bauböck (2018) provides an illuminating analysis of the complexities and pitfalls of burden-sharing for refugee protection in the European Union. Despite the fact that 'the European Union offers the best conditions that can be assumed under real world circumstances for an effective regional refugee protection regime' (Bauböck, 2018, p. 142), the author shows how this potential has not been realised due to institutional failures to Europeanise refugee policies.

\section{Social protection context as a driver of mobility and displacement}

The intersection of social protection and displacement/flight drivers is developed in Fig. 1 below. The purpose of this figure is to depict, at a general level, the relationships between inherently multi-sited drivers of displacement. The context at home and what is known about any potential destination will affect the household and individual decision to move away from a place of origin to a specific destination, but also the decision to move from one destination to another, or to return. This will affect household membership/structure and the vulnerability of some household members particularly those left behind if there is no regular income or informal care networks collapse. The choice is a dynamic one, in the sense that it takes place over multiple

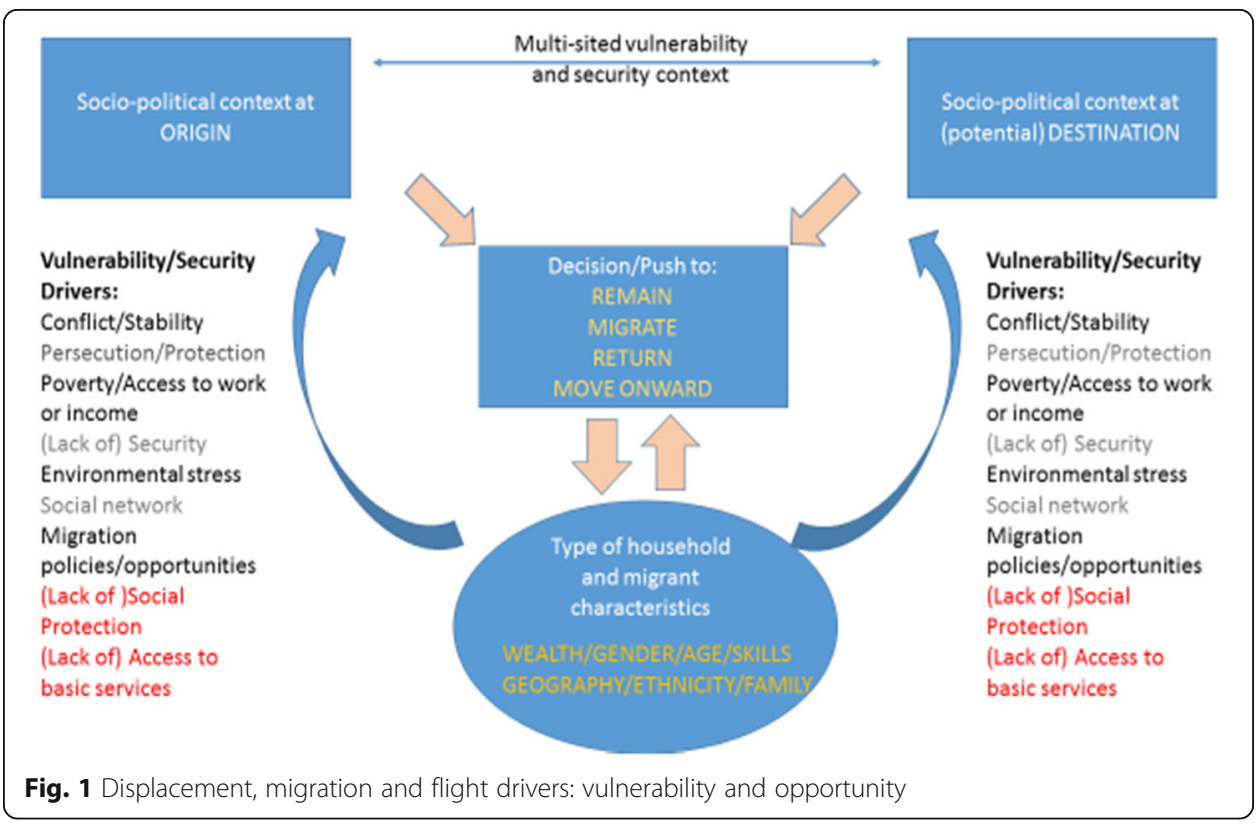


time periods and also across potential sites. Considerations of vulnerability, and of real and perceived security (both physical and income), will affect this decision, as will the quality of information available to a would-be migrant regarding potential destinations. While the factors pushing the forcibly displaced to leave are extreme, often making the social-political context of a refugee or other forcibly displaced persons' first destination less immediately relevant than its geographic proximity, socio-political context (including social protection provision and access) will often influence longer-term decisionmaking (Bakewell, van Hear, \& Long, 2012). The dynamic and multi-sited nature of the displacement and decision-making implies that movement will affect household structures, labour market decisions and care-dependency ratios. So, for instance, if an adult male earner is forced to leave a household comprised of children, elderly and one female adult, then this will have significant implications for the economic and social stability and sustainability of the household left at destination.

Much of the public discussion on forced displacement and refugees occurs in a static, one-directional framing of movement. That is, a refugee is seen as moving from one country to another and then remaining there until he/she might return or be returned. Bakewell (2008) is vocal on this in highlighting the 'sedentary bias' that shapes statecentred responses to migration in the context of conflict. But, as illustrated in the figure above, movement is dynamic and while the first move might have occurred in the context of conflict and shock, further moves might be in the context of voluntary migration for economic or social purposes.

A limited number of studies on the influence of different countries welfare and asylum support systems suggests that they are not important to a person's initial decision to migrate. However, the policies and rules of different destination countries may influence later decisions on whether to continue to another country where opportunities and conditions may be better (Kuschminder, de Bresser, \& Siegel, 2015; Triandafyllidou, 2009). An increase in onward movement may follow a cut in social provisioning resulting from a drop in humanitarian or development funding (e.g. reduced food assistance) [e.g. Syrian refugees leaving Jordan after food aid cuts; see Danish Refugee Council, 2016]. In other cases, refugees and other forced migrants may grow frustrated with receiving basic social assistance as a substitute for other rights ("care and maintenance") and engage in onward movements in the hope of securing (often irregular) access to the labour market, and a greater degree of empowerment and dignity [e.g. Somali refugees moving from Kenya; see Moret, Baglioni, \& EfionayiMader, 2006].

Winder Rossi, Spano, Sabates-Wheeler, and Kohnstamm (2017) develop a categorization of social protection contexts. Social protection strategies and interventions vary widely according the specific contexts at local level. This framework summarizes different scenarios which can be used to define the most appropriate social protection intervention strategy in a given context. The scenarios include levels of system maturity based on state capacity, as well as flexibility and capacity to respond ranging from a case in which the provision of social protection is completely absent, to a situation in which the social protection system is flexible and able to respond in an appropriate and efficient manner after a shock.

Refugees frequently move from places with shattered or non-existent social protection systems to locations with only slightly better provision (for instance, refugees 
moving from Burundi to Tanzania, where national social protection systems are nascent but access for refugees is heavily restricted). In conflicts where the state is an active party to the conflict and does not control all of its territory, then, even welldeveloped social protection systems may only be able to reach part of the population. There may also be non-conflict contexts where a social protection system is well developed, but regimes deliberately exclude particular population groups from assistance. It is precisely because of this that extra-governmental organisations, development agencies and NGOs have developed a range of social protection provisions to ease the livelihood transition and adaptation of refugees and other forcibly displaced people.

An often overlooked aspect of provision of social protection is the complex relationship between the forcibly displaced and host communities. ${ }^{11}$ In situations of substantial influxes of refugees, such as in the Kosovar-Albanian crisis of 1999, it is possible that the refugee population, on average, has more financial liquidity at their disposal than the host population. That is, the local host population may be very poor. Cash or food transfers and social support targeted only to the refugee population can further exacerbate this economic difference, causing social and economic tension between the two groups. This can lead to local price hikes and a two-tier market for host and refugee populations, as well as conflict and unrest. Governments and communities can try to minimise these tensions through various social cohesion initiatives, and also through extending provision of social protection to the host community in addition to the refugee community. Recent work by Hagen-Zanker et al. (2017) on the impacts of a cash transfer for Syrian refugees in Jordan shows that the Jordanian Government has a policy that requires equitable provision of support to both refugees and host populations. This is one way of helping to resolve local problems.

\section{Legal rights and social protection for forcibly displaced persons}

As discussed, forcibly displaced populations have specific, transnational and evolving social protection needs, yet they face particular challenges accessing formal social protection programmes upon arrival in a country of destination. The 'rights on paper' and in policy for displaced populations can at the same time provide protection but also further entrench vulnerabilities for these groups. We illustrate this below.

In her work on immigrant rights in the context of the welfare states of global North, Sainsbury (2012) describes how the 'forms of entry' determine the specific rights and restrictions for immigrants' access to social welfare. For instance, the 1951 UN Convention lays down the obligation to accord refugees the same treatment as national with regard to social benefits. On the other hand, asylum seekers have minimal rights to social provision. In other words, the conditions by which one enters a country leads to a pattern of stratification in relation to social rights (pp 17).

Refugees' rights related to social protection, as laid out in the 1951 Convention (see Table 1), include access to the labour market (Article 17); rights to self-employment (Article 18); inclusion in any rationing scheme (Article 20); access to housing (Article

\footnotetext{
${ }^{11}$ Refugees rarely enjoy de jure the same level of social protection as national citizens. Furthermore in practice, there are situations where the level of refugee assistance - even if partial and imperfect - is superior to what local citizens de facto receive from their governments in the social protection arena (usually in LDCs).
} 
21); right to public elementary education (Article 22); right to public relief (Article 23); and social security and employment legislation (Article 24). In some cases (rationing, elementary education), rights are equivalent to those of nationals; in most other cases, refugees are to be provided with 'the most favourable treatment as possible', and in any event 'not less favourable than any other migrant'. However, many states have lodged reservations against the obligations laid out in the 1951 Convention (especially Articles 17, 23 and 24).

Other States (particularly those in the Middle East, such as Lebanon) do not fully recognize these obligations in practice, even where a reservation is not in place. Refugees may often face heavy restrictions in terms of accessing local labour markets, especially when required to live in designated areas (e.g."encampment"). Provision of basic social protection (food aid, cash assistance) often falls to humanitarian agencies whose funding for such programmes may be short-term. Where social protection is inadequate in a first country of asylum, this may contribute to onward movement of refugees.

Refugee advocates argue that once recognized on a prima facie basis as a refugee, an individual should be able to presumptively enjoy all the rights, including to social protection, granted under the 1951 Convention. However, in practice states may limit prima facie refugees' access to these rights, for instance by restricting access their access to labour markets and insisting upon refugees' encampment. Furthermore, Pittaway and Bartolomei (2001) point out that the gender blindness of the Refugee Convention and international law and domestic policy relating to refugee women has been recognized only relatively recently within the international system. The Refugee Convention does not recognize persecution based on grounds of gender as a claim for refugee status, nor is it clear that violence on grounds of gender can be considered as persecution. This gender bias is often exacerbated further by humanitarian organisations working on the ground (for instance, see Grabska, 2011, for a study of gender mainstreaming in Kakuma refugee camp, Kenya).

Asylum-seeker status should be short-term and temporary. Asylum-seekers have the right not to be returned to their country of origin until their claim for refugee status is adjudicated, but any social protection rights are dependent upon national laws. In practice, asylum-seekers can wait several months or years for their claims to be heard, and asylum-seekers' rights to work or access social protection are often heavily restricted. While many OECD/industrialized states offer asylum-seekers limited state support (housing, basic income support), levels of social assistance are often inadequate, and in these and many other settings asylum-seekers must often rely upon NGO and charitable assistance. This may contribute to onward movement of asylum-seekers away from states with slow asylum processing systems and limited rights for those waiting for a determination.

Internally Displaced Persons are very often citizens of the country in which they are resident and in other cases are for the most part habitual residents, many with similar rights to nationals. The cornerstone of IDP protection is non-discrimination, i.e. equal recognition of IDPs' rights without regard to their displacement. This includes their rights to social protection, which should be recognized as equivalent to those other citizens or habitual residents. However, as a result of their forced displacement, IDPs may face specific challenges in realizing their rights, especially if a state is actively hostile to 
the IDP group (e.g. ethnic discrimination) or where conflict or natural disaster has destroyed infrastructure and weakened state capacity. In such cases, the ability of IDPs to secure basic social protection - food, housing, healthcare - may depend upon international organisations' programmes, and their access to the labour market may be limited. A failure to provide adequate social protection to IDPs may contribute to their onward movement and secondary displacement, either within the country or beyond its borders (so that IDPs become refugees). Even where resettlement is an option, Pittaway and Bartolomei (2001) show that resettlement policies actively discriminate against women on grounds of both race and gender. ${ }^{12}$

\section{Constraints and opportunities: designing social protection systems that can accommodate forcibly displaced populations}

In recent years, refugees and forcibly displaced populations have attracted enormous media attention as an increasing number of disasters and political conflicts push more and more people to move away from their homes and seek refuge and opportunities in other places. The rise of the political right in a number of western nations, together with nervousness about the financial and institutional capability of 'receiving' locations to adequately respond to the needs of these large-scale population movements, means that the space for thinking about the rights and needs of people on the move has become limited and increasingly political. Nonetheless, it is precisely because of these global trends that the plight of forcibly displaced populations (including refugees) is becoming more precarious and vulnerable.

Counteracting these constraints are the global commitments to the Sustainable Development Goals (SDGs) and a 'leave no one behind' agenda, social protection for all under the Universal Declaration of Human Rights and the Global Social Protection Floor initiative, and most recently the Comprehensive Refugee Response Framework (CRRF) - adopted in 2016 by all 193 member states. With regard to forced displacement, in particular, there has been no time as pressing as the current to think innovatively about universal workable solutions for people on the move. The SDGs take us some way towards this, but there is obvious space for innovations in social protection implementation and delivery for people on the move, for non-citizen populations, for refugees and the forcibly displaced.

The international policy context, together with increasing migrant flows, has created an appetite for ensuring that human rights are available to all forcibly displaced populations. Protecting these groups against insecurity and deprivation requires commitment at both political and practical levels. In states where there are well-developed social protections for citizens (such as the UK), the inclusion of refugees and other forcibly displaced people in these systems is generally preferable to the development of parallel programmes delivered by international or national humanitarian. However, there may be resistance to state-led provision and/or specific circumstances (e.g. rural and isolated refugee camps with no close local population; a weak host state; a hostile state) where it is more appropriate or realistic for social protection to be delivered and financed by non-state actors. This can introduce challenges related to financial sustainability and

\footnotetext{
${ }^{12}$ For other forcibly displaced people granted some form of temporary protection, their access to social assistance and social services is dependent upon national law.
} 
the duration of provision, undermining any entitlement/rights intention of the provision, as well as raising questions about accountability. Such issues underline the importance of efforts to move from fragmented short-term humanitarian funding to more predictable long-term models which have some of the characteristics of a state led system (e.g. common targeting, registration, financing etc.), although led by international actors. This can be complicated, as even when well-developed social protection systems for citizens are in existence many states hosting forcibly displaced people may be unable to afford - financially or politically - to include these groups without international financial assistance.

Despite this, opportunities are emerging from within the evolving field of shockresponsive social protection that encourages us to innovate for the inclusion of displaced populations. What was once a deeply held belief that the needs of the displaced could only be met through humanitarian assistance, is now being challenged as the international community seeks to trial ways to harmonise humanitarian response within social protection systems - through targeting, beneficiary registration, payment and delivery.

A recent new focus on shock-responsive social protection means that donor and development agencies are supporting Governments to build national programmes that are able to scale up and down according to seasonal needs and in response to shocks (O'Brien, Cherrier, Watson, \& Congrave, 2017). Social protection programmes are increasingly being designed with specific mechanisms that enhance their flexibility to respond in the event of crises, including, contingency funds, price indexing to respond to seasonal or unexpected variability, expanded management and information systems (MIS), as well as pre-determined plans to be able to scale up (eg: expansion in number of beneficiaries and/or increase in size of transfer). This is an important area of programming where migrants and refugee's needs can potentially be catered for within planning and projections of caseloads. Two examples of this kind of programming are the Productive Safety Net Programme (PSNP) in Ethiopia and the Hunger Safety Net Programme (HSNP) in Kenya.

While the contingency funds and risk financing facility has been used in Ethiopia quite successfully in recent years, and the HSNP flexible response function has been praised for its ability to quickly scale up and out, whether forcibly displaced people have benefitted from these systems, en masse, is unlikely and has not yet been evaluated. The discretion for local level administrators to apply the contingency funds means that some categories of vulnerable migrants and displaced people might be fortunate enough to access transfers in times of crisis. However, neither the PSNP nor the HNSP are set up to respond to large numbers of people on the move, as in the case of refugees on IDP movements. This is because the programmes are targeted to citizens (through ID requirements in targeting) and the funds available for contingency would not be able to support huge numbers of additional claimants. For this reason, largescale movements are dealt with through the humanitarian sector, in conjunction with the international community.

Even in those rare cases where displaced individuals or households may be able to benefit from the horizontal expansion in the system, in practice expansion to mobile households is very complicated. Simply by being mobile, it may be too difficult and costly to locate the household and deliver the transfer. The increasing use of mobile 
and digital technology means that there is ample space to innovate in this area. For instance, cash transfers delivered through e-payments means that beneficiaries are not tied to a place of payment.

Regardless of circumstance, states are rarely the only providers of social protection. It is important to note the role played by informal social protection - remittances, for instance, are often an essential component of social protection for many refugee and displaced families. ${ }^{13}$ We might consider the balance of provision not just between the state, market and family, but also the social networks and parallel systems of provision, which both serve migrants and displaced populations, but also reinforce their exclusions for the mainstream (Prasad-Aleyamma, 2011).

In a similar vein, recent research by Easton-Calabria and Pincoc (2018) in Uganda and Kenya 'reveals the ways in which refugees are working to support, protect, advocate for and transform the prospects of their communities' (pp. 56). They term this 'refugee-led social protection', which 'includes activities to address vulnerability, such as providing food, shelter, education and health care, but also involves advocacy and the resulting transformation of local and international structures, such as laws and humanitarian systems, which may hinder rather than enable refugees' access to such provisions' (pp. 56).

From the point of view of disadvantaged groups, such as, women, ethnic minorities, the elderly and migrants, the organization of social protection and welfare is crucial in shaping both their eligibility and address to decommodified benefits, and also in defining and reinforcing their subordinate statuses (Orloff, 1993; Rosenhek, 1999).

Furthermore, international actors and states can work to help strengthen informal forms of social protection, for instance by working to reduce remittance costs. This is important because the current global political climate - in particular, widespread popular anxieties about the arrival of refugees, asylum-seekers and migrants in local communities - has reduced these groups' access to state-based social protection, both by narrowing opportunities for legal mobility and by limiting access to social protection upon arrival.

\section{Conclusions}

As a policy instrument for dealing with vulnerability, access to social protection provision is particularly pertinent for those people and populations who are made vulnerable due to persecution, conflict and displacement. Gender further exacerbates the vulnerability to poverty, rights abuse and exploitation that are frequently associated with displacement. Furthermore, family structure and lifecycle mediates how vulnerability through the care economy plays out when one or more family member is 'displaced.' Forced displacement frequently leads to vulnerabilities that require specific social protection instruments. This is pertinent for women, children and older migrants who are, frequently by nature of their age and gender, left behind in highly vulnerable and dependent situations, or are unwilling/unable to take the risks required to move again. Compounding this disadvantage, the vast majority of refugees and other forcibly displaced people are hosted in states where social protection coverage is often severely limited even for citizens. ${ }^{14}$

\footnotetext{
${ }^{13}$ There is a vast literature on the role of remittances in social provisioning for refugees and migrants. We do not cover this here.

${ }^{14} 86 \%$ of refugees, for instance, are hosted in the developing world. UNHCR, Global Trends: Forced Displacement in 2015, June 2016, http://www.unhcr.org/576408cd7.pdf, p.2.
} 
Standard social protection frameworks, in the main, do not attend to the plight of refugees and forcibly displaced people and their relation to welfare. This is largely because these framings do not incorporate institutional, social and political challenges to welfare provision, which are characteristics of displacement-specific vulnerability. Despite increased global recognition of the role that formal social protection can play in reducing vulnerabilities and building resilience and national and international political commitment to expanding formal social protection, significant gaps and barriers to access remain. This is especially true for refugees, asylum seekers and other forcibly displaced populations who frequently find themselves in territories or places where their rights to formal social protection are heavily restricted, or where access barriers are so high that they are unable to take advantage of provision even where it is available (Ambrosini, 2018; Sainsbury, 2012). Critically, for populations on the margins, such as children, women and older people, policies covering forcibly displaced persons rights, including policies on refugees, resettlement, repatriation and integration need to be recast and applied in a way that pro-actively addresses gendered and generational vulnerabilities and needs.

The SDGs, the CRRF, and recent interest in integrating social protection and humanitarian response to crisis through scalable safety-nets, give us a real opportunity to think about how to best serve the social protection needs of forcibly displaced populations. There are a number of opportunities for social protection programming to be tailored to help reduce the vulnerabilities of these groups, prior to departure, during the journey, upon arrival in a country of destination, and at the point of return. These include piggy backing extra-state provision for refugees onto established state systems of the social provision for refugees, such as in the case of Syrian refugees in Jordan. It could also include the use of e-payment linked to cash transfers. Social protection mechanisms in the form of social transfers (cash, food, vouchers or assets), social welfare services or occupation-linked insurance will be appropriate to different situations at different times, and may be provided by a range of actors (State, market, donors, CBOs, NGOs and relatives). New work on social protection contexts help us to identify the best-placed actors to deliver social protection for displaced populations in each context. Furthermore, the move to harmonize humanitarian and social protection instruments and systems will open up space to offer more reliable social protection for these vulnerable groups. For instance, efforts to align targeting and monitoring systems between the humanitarian and social sectors will ensure that the acutely poor and vulnerable (such as, refugees and IDPs affected by conflict or natural fast onset shocks) are retained within a system of possible beneficiaries and are more likely to benefit from long term support as development actors take over from where humanitarians leave off.

In addition, more empirical research - including real-time evaluation of the impact of social protection interventions - is needed in order to better use social protection to meet forcibly displaced peoples' needs and vulnerabilities, and to better understand the role social protection plays in shaping peoples' decisions to move. Inclusive innovations in social protection for the forcibly displaced will include complementary interventions that promote social integration, the removal of information bottlenecks, sensitivity to language and culture in the design of social protection instruments and advances in digital payment delivery and targeting. 


\section{Acknowledgements}

This paper draws upon and extends a paper prepared for DFID and co-authored with Katy Long. See Long and Sabates-Wheeler (2017). I would like to thank Katy Long for her input and suggestions.

Authors' contributions

RSW is the sole author of this article. The author read and approved the final manuscript.

\section{Funding}

Not applicable.

\section{Availability of data and materials}

Not applicable.

\section{Competing interests}

The author declares that she has no competing interests.

Received: 15 June 2018 Accepted: 15 July 2019

Published online: 09 September 2019

\section{References}

Ambrosini, M. (2017). Why irregular migrants arrive and remain: The role of intermediaries. Journal of Ethnic and Migration Studies, 43(11), 1813-1830.

Ambrosini, M. (2018). Irregular immigration in Southern Europe: Actors, dynamics and governance. Springer.

Avato, J., Koettl, J., \& Sabates-Wheeler, R. (2010). Social security regimes, global estimates, and good practices: The status of social protection for international migrants. World Development, 38(4), 455-466.

Bakewell, O. (2008). Keeping them in their place: The ambivalent relationship between development and migration in Africa. Third World Quarterly, 29(7), 1341-1358.

Bakewell, O., van Hear, N., \& Long, K. (2012). Drivers of migration. Migrating out of poverty (RPC Working Paper No.1). Brighton: Migrating out of Poverty Consortium, University of Sussex.

Barglowski, K., Krzyżowski, Ł., \& Świątek, P. (2015). Caregiving in Polish-German transnational social space: Circulating narratives and intersecting heterogeneities. Population, Space and Place, 21(3), 257-269.

Barrientos, A., \& Hulme, D. (2008). Social Protection for the Poor and Poorest: An Introduction. In A. Barrientos, \& D.Hulme (Eds.), Social Protection for the Poor and Poorest (pp. 3-24). London, UK: Palgrave Studies in Development. Palgrave Macmillan. https://doi.org/10.1057/978-0-230-58309-2_1

Bartolomei, L., Pittaway, E., \& Pittaway, E. E. (2003). Who am I? Identity and citizenship in Kakuma refugee camp in northern Kenya. Development, 46(3), 87-93.

Bauböck, R. (2018). Refugee protection and burden-sharing in the European Union. Journal of Common Market Studies, 56(1), 141-156.

Bilecen, B., \& Barglowski, K. (2015). 'On the assemblages of informal and formal transnational social protection', population Space and Place, 21, 203-214.

Boccagni, P. (2011). Migrants' social protection as a transnational process: Public policies and emigrant initiative in the case of Ecuador. International Journal of Social Welfare, 20(3), 318-325.

Danish Refugee Council. (2016). Going to Europe: A Syrian perspective. Middle East and North Africa, Regional Report. Retrieved from https://drc.ngo/media/2126540/drc-going-to-europe-report-pdf.pdf

Devereux, S., \& Sabates-Wheeler, R. (2004). Transformative social protection (IDS Working Paper No. 232). Brighton: Institute of Development Studies. Retrieved from https:/www.unicef.org/socialpolicy/files/Transformative_Social_Protection.pdf

Easton-Calabria, E.. \& Pincock, K. (2018, June). Refugee-led social protection: Reconceiving refugee assistance. Forced Migration Review 58. Retrieved from https://www.fmreview.org/economies

Gentilini, U., \& Omamo, S. W. (2011). Social protection 2.0: Exploring issues, evidence and debates in a globalizing world. Food Policy, 36(3), 329-340.

Grabska, K. (2011). Constructing 'modern gendered civilised'women and men: Gender-mainstreaming in refugee camps. Gender and Development, 19(1), 81-93.

Hagen-Zanker, J., Ulrichs, M., Holmes, R., \& Nimeh, Z. (2017). Cash transfers for refugees: The economic and social effects of a programme in Jordan. Research Reports and Studies. London: ODI.

Kofman, E., \& Raghuram, P. (2010). The Implications of Migration for Gender and Care Regimes in the South. In K. Hujo, \& N. Piper, (Eds.), South-South Migration: Challenges for development and social policy. UK: Palgrave Macmillan. Retrieved from https://www.springerprofessional.de/en/the-implications-of-migration-for-gender-and-care-regimes-in-the/7214562

Kuschminder, K., de Bresser, J., \& Siegel, M. (2015). Irregular migration routes to Europe and factors influencing migrants destination choices. Maastricht: Maastricht Graduate School of Governance.

Long, K., \& Sabates-Wheeler, R. (2017). Migration, Forced Displacement and Social Protection. (GSDRC Rapid Literature Review). Birmingham: University of Birmingham. Retrieved from https://tinyurl.com/y84ofco4

MacAuslan, I. (2011). Crossing Internal Boundaries: Political and Physical Access to the Public Distribution System in India. In R. Sabates-Wheeler, \& R. Feldman (Eds.), Migration and Social Protection. Rethinking International Development Series. London: Palgrave Macmillan. https://doi.org/10.1057/9780230306554_8

Moret J, Baglioni, S., Efionayi-Mader, D. (2006). The path of Somali refugees into exile: A comparative analysis of secondary movements and policy response (SFM studies 46). Swiss Forum for Migration and Population Studies,

O'Brien, C., Cherrier, C., Watson, C., \& Congrave, J. (2017). Shock-responsive social protection systems research: Case study-Regional approaches to addressing food insecurity in the Sahel, and the contribution of social protection. Oxford: Oxford Policy Management.

Olivier, M. (2009). Regional overview of social protection for non-citizens in the Southern African Development Community (SADC). (World Bank Social Protection Discussion Paper). 
Orloff, A. S. (1993). Gender and the social rights of citizenship: The comparative analysis of gender relations and welfare states. American sociological review, 303-328.

Pittaway, E., \& Bartolomei, L. (2001). Refugees, Race, and Gender: The Multiple Discrimination against Refugee Women. Refuge: Canada's Journal on Refugees, 19(6), 21-32. Retrieved from https://refuge.journals.yorku.ca/index.php/refuge/article/ view/21236

Pittaway, E., \& Rees, S. (2006). Multiple Jeopardy: Domestic violence and the notion of cumulative risk for women in refugee camps. Women Against Violence: An Australian Feminist Journal, 18, 18-25.

Pittaway, E., \& Bartolomei, L. (2018). Enhancing the protection of women and girls through the global compact on refugees. Forced Migration Review, 57, 77-79.

Pong, M. (2014). Educating the children of migrant workers in Beijing: Migration, education, and policy in urban China. Routledge, Abingdon, UK.

Prasad-Aleyamma, M. (2011). A Market Place for Migrants: Mobility, Settlement and Social Protection in Kerala. In R. SabatesWheeler, \& R. Feldman (Eds.), Migration and social protection (pp. 164-182). London: Palgrave Macmillan.

Rosenhek, Z. (1999). The exclusionary logic of the welfare state: Palestinian citizens in the Israeli welfare state. International Sociology, 14(2), 195-215

Sabates-Wheeler, R., Abdulai, A. G., Wilmink, N., De Groot, R., \& Spadafora, T. R. (2017). Linking social rights to active citizenship for the most vulnerable. UNICEF, Innocenti working paper, WP-2017-14.

Sabates-Wheeler, R., \& Devereux, S. (2008). 'Transformative social protection: The currency of social justice'. In A. Barrientos \& D. Hulme (Eds.), Social Protection for the Poor and Poorest. Risk, Needs and Rights. London: Palgrave.

Sabates-Wheeler, R., \& Devereux, S. (2013). Transforming livelihoods for resilient futures: How to facilitate graduation in social protection programmes. Development and Change, 35(4), 274-285.

Sabates-Wheeler, R., \& Feldman, R. (2011). Migration and social protection: Claiming social rights beyond borders. Rethinking International Development Series. Palgrave Macmillan, BAsingstoke, UK.

Sabates-Wheeler, R., \& Waite, M. (2003). Migration and Social Protection: A Concept Paper (Development Research Centre on Migration, Globalisation and Poverty Working Paper Series, T2). Sussex: Sussex University. Retrieved from https://www. researchgate.net/profile/Rachel_Sabates-Wheeler/publication/242553905_Migration_and_Social_Protection_A_Concept_ Paper/links/02e7e538867037fa36000000.pdf

Sainsbury, D. (2012). Welfare states and immigrant rights: The politics of inclusion and exclusion. Oxford University Press, Oxford, UK.

Surender, R., \& Walker, R. (Eds.). (2013). Social policy in a developing world. Edward Elgar Publishing. Cheltenham, UK

Triandafyllidou, A. (2009). Greek immigration policy at the turn of the 21st century. Lack of political will or purposeful mismanagement? European Journal of Migration and Law, 11(2), 159-177.

Winder Rossi, N., Spano, F., Sabates-Wheeler, R., \& Kohnstamm, S. (2017). Social protection and resilience building: Supporting livelihoods in protracted crises, Fragile and Humanitarian Contexts (FAO position paper). Rome, Food and Agriculture Organization of the United Nations. Institute for Development Studies. Retrieved from http://www.fao.org/3/a-i7606e.pdf

\section{Publisher's Note}

Springer Nature remains neutral with regard to jurisdictional claims in published maps and institutional affiliations.

\section{Submit your manuscript to a SpringerOpen ${ }^{\circ}$ journal and benefit from:}

- Convenient online submission

- Rigorous peer review

- Open access: articles freely available online

- High visibility within the field

- Retaining the copyright to your article

Submit your next manuscript at $\boldsymbol{\nabla}$ springeropen.com 